\title{
Performance and Profitability of Fungicides for Managing Soybean White Mold: A 10-Year Summary of Cooperative Trials
}

\author{
Jhonatan P. Barro, ${ }^{1}$ Maurício C. Meyer, ${ }^{2}$ Claúdia V. Godoy, ${ }^{2}$ Alfredo R. Dias, ${ }^{3}$ Carlos M. Utiamada, ${ }^{4}$ David de S. Jaccoud Filho, ${ }^{5}$ \\ Dulândula S. M. Wruck, ${ }^{6}$ Edson P. Borges, ${ }^{3}$ Fabiano Siqueri, ${ }^{7}$ Fernando C. Juliatti, ${ }^{8}$ Hércules D. Campos, ${ }^{9}$ José N. Junior, ${ }^{10}$ Luciana \\ C. Carneiro, ${ }^{11}$ Luis H. C. P. da Silva, ${ }^{12}$ Mônica C. Martins, ${ }^{13}$ Ricardo S. Balardin, ${ }^{14}$ Roberto K. Zito, ${ }^{2}$ Silvânia H. Furlan, ${ }^{15}$ Wilson S. \\ Venancio, ${ }^{16}$ and Emerson M. Del Ponte ${ }^{1, \dagger}$ \\ ${ }^{1}$ Departamento de Fitopatologia, Universidade Federal de Viçosa, 36570-000 Viçosa, MG, Brazil \\ ${ }^{2}$ Embrapa Soja, 86001-970 Londrina, PR, Brazil \\ ${ }^{3}$ Fundação Chapadão, 79560-000 Chapadão do Sul, MS, Brazil \\ ${ }^{4}$ TAGRO - Tecnologia Agropecuária Ltda, 86070-460 Londrina, PR, Brazil \\ ${ }^{5}$ Departamento de Fitotecnia e Fitossanidade, Universidade Estadual de Ponta Grossa, 84030-900 Ponta Grossa, PR, Brazil \\ ${ }^{6}$ Embrapa Agrossilvipastoril, 78550-970 Sinop, MT, Brazil \\ ${ }^{7}$ Fundação Mato Grosso, 78750-000 Rondonópolis, MT, Brazil \\ ${ }^{8}$ Universidade Federal de Uberlândia, 38400-902 Uberlândia, MG, Brazil \\ ${ }^{9}$ Universidade de Rio Verde, 75901-970 Rio Verde, GO, Brazil \\ ${ }^{10}$ Centro Tecnológico para Pesquisas Agropecuárias, 74130-010 Goiânia, GO, Brazil \\ ${ }^{11}$ Universidade Federal de Goiás, 75801-615 Jataí, GO, Brazil \\ ${ }^{12}$ AgroCarregal, 75900-000 Rio Verde, GO, Brazil \\ ${ }^{13}$ Círculo Verde Assessoria Agronômica e Pesquisa, 47850-000 Luís Eduardo Magalhães, BA, Brazil \\ ${ }^{14}$ Universidade Federal de Santa Maria, 97111-970 Santa Maria, RS, Brazil \\ ${ }^{15}$ Instituto Biológico, 04014-900 São Paulo, SP, Brazil \\ ${ }^{16}$ CWR Pesquisa Agrícola, 84035-130 Ponta Grossa, PR, Brazil
}

\begin{abstract}
White mold, caused by Sclerotinia sclerotiorum, is a yield-limiting disease of soybean in Brazil. Uniform fungicide trials have been conducted annually since 2009. Data from 74 cooperative field trials conducted over a 10-year period were assembled. We selected five fungicides applied two times around flowering: dimoxystrobin plus boscalid (DIMO+ BOSC), carbendazim plus procymidone (CARB+PROC), fluazinam (FLUZ), fluopyram (FLUO), and procymidone (PROC). For comparison, thiophanate-methyl (TMET) applied four times was also included as a low-cost treatment. Network models were fitted to the log of white mold incidence (percentages) and log of sclerotia mass data (grams/hectare) and to the nontransformed yield data (kilograms/hectare) for each treatment, including the untreated check. Back-transformation of the

and 83.8 (79.1 to 87.5 ) and $87 \%$ (81.9 to 91.6) for CARB+PROC, respectively. The overall mean $(95 \% \mathrm{CI})$ yield responses ranged from $323 \mathrm{~kg} / \mathrm{ha}$ (247.4 to 400.3) for TMET to $626 \mathrm{~kg} / \mathrm{ha}$ (521.7 to 731.7) for DIMO+ BOSC, but the variance was significantly reduced by a binary variable (30\% threshold) describing disease incidence in the untreated check. On average, an increment of $352 \mathrm{~kg} / \mathrm{ha}$ was estimated for trials where the incidence was $>30 \%$ compared with the low-disease scenario. Hence, the probability of breaking even on fungicide costs for the high-disease scenario was $>65 \%$ for the more effective, but more expensive fungicide (FLUZ) than TMET. For the low-disease scenario, profitability was less likely and depended more on variations in fungicide cost and soybean price.
\end{abstract} meta-analytic estimates indicated that the lowest and highest mean (95\% confidence interval $[\mathrm{CI}]$ ) percent reductions in incidence and sclerotia mass were 54.2 (49.3 to 58.7 ) and $51.6 \%$ (43.7 to 58.3) for TMET
Keywords: chemical control, disease management, economic impacts, field crops, fungi, legumes, oilseeds, yield loss
White mold, also known as Sclerotinia stem rot, is a damaging disease of worldwide importance for several crops, including common bean (Phaseolus vulgaris L.), canola (Brassica napus L.), cotton (Gossypium hirsutum L.), potato (Solanum tuberosum L.), soybean (Glycine max L.), and sunflower (Helianthus annuus L.) (Boland

${ }^{\dagger}$ Corresponding author: E. M. Del Ponte; delponte@ufv.br

Funding: This work was supported by a Universidade Federal de Viçosa Programa de Pós-graduação em Fitopatologia and Conselho Nacional de Desenvolvimento Científico e Tecnológico (CNPq) graduate scholarship to J. P. Barro and a CNPq research fellowship to E. M. Del Ponte.

*The $\boldsymbol{e}$-Xtra logo stands for "electronic extra" and indicates that one supplementary file is published online.

The author(s) declare no conflict of interest.

Accepted for publication 26 February 2019.

() 2019 The American Phytopathological Society and Hall 1994). Symptoms of the disease include water-soaked stem lesions that acquire light brown coloration, resulting in the appearance of dense white mycelium; severely affected plants may wilt and die prematurely (Peltier et al. 2012). In Brazil, soybean yield losses attributable to white mold may reach 50 to $70 \%$, especially in high-elevation regions $(>600 \mathrm{~m})$ where cooler weather conditions favor the disease (Lehner et al. 2016). White mold is considered endemic to approximately $23 \%(\approx 7.7$ million ha) of the soybean production area in Brazil (Meyer et al. 2016a). In the United States, estimates of cumulative economic losses as a result of white mold were 2.8 million metric tons between 2010 and 2014, with an estimated cost of $\$ 1.2$ billion USD (Allen et al. 2017; Willbur et al. 2019).

White mold is caused by Sclerotinia sclerotiorum (Lib.) de Bary, an ascomycete fungus that is capable of surviving and remaining viable for several years in soil in the form of sclerotia (hard dark resting bodies consisting of a mass of hyphal threads) (Adams and Ayers 1979). During moist periods and cooler temperatures $\left(10\right.$ to $\left.21^{\circ} \mathrm{C}\right)$, sclerotia germinate and produce multiple apothecia that release ascospores, the primary inoculum (Adams and Ayers 1979; Clarkson et al. 2014; Schwartz and Steadman 1978). Ascospores are easily 
dispersed throughout the canopy and escape to the atmosphere by air currents. When flowering stages are reached, ascospores are capable of infecting the petals during disease-inducing environmental conditions (temperature between 15 to $25^{\circ} \mathrm{C}$ and leaf wetness of a minimum of 2 to $4 \mathrm{~h}$ ) (Young et al. 2004). The infected senescing flowers provide a nutrient source and means for the fungus to disperse throughout the canopy (petalborne inoculum) and infect the stem and leaves. White-cottony mycelia are then formed, which eventually produce dark sclerotia of variable size (Abawi and Grogan 1975; Boland and Hall 1994; Fall et al. 2018; Lehner et al. 2016).

The disease is best managed by integrating multiple management practices, including host resistance, use of healthy/treated seed, rotation with nonhost species (grasses), shifted planting dates, modification of row spacing and seed density to avoid a dense canopy, and application of biological agents and fungicides (Meyer et al. 2014; Mueller et al. 2002; Peltier et al. 2012; Vieira et al. 2010; Willbur et al. 2019; Wutzki et al. 2016). Among all tactics, the use of chemical fungicides remains the most effective tool for protecting soybean plants during flowering when the primary infection takes place (Meyer et al. 2016a; Mueller et al. 2002; Sumida et al. 2015; Wutzki et al. 2016).

In Brazil, several active ingredients (a.i.) from different chemical groups and modes of action have been suggested for white mold management, including fluazinam (FLUZ; inhibits oxidative phosphorylation, acting on the pathogen's respiration), procymidone (PROC; acts on osmoregulation of the fungal membranes), thiophanate-methyl (TMET; inhibits mitotic division by disturbing the assemblage of microtubules), and boscalid (BOSC; inhibits succinate dehydrogenase, which acts on stage II of fungus respiration) (Brent and Hollomon 2007; Lehner et al. 2017; Meyer et al. 2014, 2017).

A cooperative trial network was established in Brazil in 2008 to evaluate the efficacy of fungicides against white mold, and results have been reported for individual seasons (Meyer et al. 2014). As expected, fungicide chemistries performed differently and variations, or inconsistencies, when comparing treatments or the same treatment at different site-years are attributable to differences in the formulation, dose, number of fungicide sprays, inoculum concentrations, and seasonal environment affecting disease and fungicide performance. A previous study in Brazil summarized the performance, yield benefits, and economics of one fungicide (FLUZ) evaluated in several trials conducted in the state of Paraná, in the south of Brazil (Tupich et al. 2017).

In the current study, we used a meta-analytical approach to summarize the effect size (e.g., percent control and yield response) of fungicide treatments (Madden et al. 2016). Meta-analysis has gained popularity as an approach for summarizing fungicide performance in plant disease management (Belova et al. 2013; Machado et al. 2017; Ojiambo et al. 2010; Paul et al. 2008, 2011). When multiple comparisons among treatments are of interest, network meta-analysis (NMA) has been recommended as a more powerful approach that provides more precise estimates and overcomes the limitations of traditional pairwise meta-analysis, which compares only two treatments at a time and thus does not take within-study correlations into account (Madden et al. 2016).

NMA was originally developed to use data generated from trials with two arms (link between two treatments) and with a common comparator, thus allowing the indirect comparison of three treatments (A versus B; B versus C). In fact, current NMA involves more than one common comparator (the linking treatment), which simultaneously allows both direct and indirect results from all study arms into a single pooled effect (Salanti et al. 2008). The most common approach to NMA in plant pathology is the arm-based modeling, also known as the unconditional model, in which treatment means (and not the contrasts) are used as effect sizes (Madden et al. 2016). Several studies have fitted network models to fungicide trial data to obtain estimates of control efficacy and crop yield response (Machado et al. 2017; Madden et al. 2016; Ngugi et al. 2011; Paul et al. 2008).

Our main objective was to summarize the yield response, but also the relative reduction (percent control efficacy) of white mold disease incidence and sclerotia production, to selected fungicide treatments evaluated during 10 growing seasons across several locations in Brazil. In addition, economic benefits were explored using the means and respective variances of meta-analytic estimates of yield response, which were used to calculate the probability of breaking even on costs considering a range of scenarios, including varying soybean prices and fungicide costs.

\section{Materials and Methods}

Data source and experimental procedures. A database on soybean yield and disease (white mold incidence and sclerotia mass) was obtained from the Ensaios Cooperativos da Rede de Mofo Branco national cooperative white mold trial network. These trials were first established in 2008 for evaluation of the performance of both registered and nonregistered fungicides against soybean white mold. Most of the data used in our study were published as yearly summaries, in which a combined analysis approach was used for comparing means (multiple comparisons) of white mold incidence (percentages), sclerotia mass (grams), and soybean yield (kilograms/hectare) across all evaluated fungicide treatments within the same year. These reports were produced for yearly uniform trials conducted in the 2013/2014 (Meyer et al. 2015b), 2014/2015 (Meyer et al. 2015a), 2015/2016 (Meyer et al. 2016b), 2016/2017 (Meyer et al. 2017), and 2107/2018 (Meyer et al. 2018) growing seasons. The data from 2012/2013 have not been published (Meyer et al., personal communication) and data from the 2008/2009 to 2011/2012 seasons were available at the trial level (multiple comparisons made within a trial) in an earlier four-season summary report (Meyer et al. 2014). Data from the latter study were used in a previous metaanalysis of the disease incidence-soybean yield relationship (Lehner et al. 2016).

The cooperative trials were conducted following a standard protocol as described elsewhere (Lehner et al. 2016). Briefly, the fungicides were applied two, three, or four times using a backpack sprayer pressurized by $\mathrm{CO}_{2}$ with a spray volume of 150 to 200 liter/ha. The first application was made between the beginning flowering (R1) and full flowering (R2) growth stages, with subsequent applications at a fixed 10-day interval. Experiments were conducted in a randomized complete block design with four replications for each treatment, including the nontreated check. Plots were $6 \mathrm{~m}$ long with six rows spaced at 0.45 or $0.5 \mathrm{~m}\left(16.5\right.$ or $\left.18 \mathrm{~m}^{2}\right)$.

White mold and yield variables. White mold intensity was assessed either at the beginning seed (R5) or full seed (R6) growth stage across trials. Incidence, or the percentage of diseased plants in the sample, was calculated based on the visual binary scores $(0$, healthy; 1 , symptomatic) assigned to each plant in the center two rows of the plot. The center four rows of the plot were harvested either by hand or using a small-plot combiner. To prevent sclerotia from being blown out of the back of the plot combiner, the fan speed was decreased compared with normal operation so the sclerotia could remain associated with the grain sample. When plants were hand harvested, they were passed through a thresher to obtain the grain plus sclerotia sample. In both cases, the sclerotia were manually separated from the grain. Grain weight and moisture were obtained after the sclerotia were removed, and crop yield was expressed as kilograms/hectare at $13 \%$ moisture. Sclerotia weight data were transformed to grams/hectare.

Criteria for treatment selection. To be included in the analysis, a fungicide treatment should have been present in at least 20 trials and over a period of 4 years. All fungicide treatments that matched the criteria, except one treatment, were applied two times: at early flowering (R1/R2) and 10 days later, including dimoxystrobin (DIMO) plus BOSC, carbendazim (CARB) plus PROC, FLUZ, fluopyram (FLUO), and PROC. The only fungicide treatment applied four times on a 10-day interval starting at R1/R2 was the benzimidazole, TMET. This four-spray treatment (evaluated in 48 trials conducted during nine growing seasons) was included in our analysis because it is a more cost-effective fungicide. Complete information for the selected fungicide treatments is presented in Table 1.

After treatment selection, the database (with raw data at the plot [block] level; four replicates) contained data from 74 independent 
trials conducted at 22 locations across eight Brazilian states. The states were grouped into the Northern region ( $n=46$ trials; Mato Grosso do Sul, Mato Grosso, Minas Gerais, Goiás, and Bahia states) and the Southern region ( $n=28$ trials; São Paulo, Paraná, and Rio Grande do Sul states). In the Northern region, most of the trials were conducted in Goiás ( $n=29$ trials). In the Southern region, most trials were conducted in Paraná $(n=24$ trials). Together with Goiás, these trials accounted for $71.6 \%$ of all trials. During the 10 -year period, the season with the largest number of trials $(n=12)$ was $2011 / 2012$, followed by $2015 / 2016(n=10)$.

The number of trials was not the same for the two response variables because some measurements were not obtained in all trials (e.g., sclerotia production, which was not evaluated in 16 trials, and soybean yield, which was not evaluated in one trial). Therefore, data were available from all 74 trials for disease incidence, from 58 trials for sclerotia production, and from 73 trials for yield.

Within the NMA context, the number of study designs (or study types), in which design describes the unique combination of fungicide treatments in a study (trial, in our case) (e.g., design $1=$ TMET, PROC, and FLUZ; design 2 = TMET, PROC, and FLUO; etc.) (Machado et al. 2017; Madden et al. 2016; Piepho 2014), was five for yield and disease incidence and eight for sclerotia production.

These study designs composed a network of treatments in which both direct and indirect evidence of comparison was used in NMAs (Madden et al. 2016). A network graph is composed of nodes (fungicide treatments) and edges or links between two treatments directly compared in the same trial. The corresponding graph allows the visualization of the number of direct comparisons between two fungicide treatments, as depicted by the thickness of the edges and the numbers presented at the top of the links (Machado et al. 2017).

Meta-analytic models. Although data were available at the plot level for most trials, an aggregated measure (means of the treatment for each variable of interest) was obtained at the trial level, which is a typical approach used in meta-analysis (Madden et al. 2016). For this approach, a measure of within-study variability (inverse of the sampling variance) is required to weight studies based on sampling variance. Given the availability of data at the plot (block) level, the required within-study sampling variance was obtained from the standard deviation of the four replicates, as an alternative to the mean square error of an analysis of variance model fitted to the trial data as used elsewhere (Machado et al. 2017; Paul et al. 2008).

The main variable of interest in the current study was the yield response measured as the difference (mostly positive) between yield in the fungicide-treated plots and the nontreated plots (Machado et al. 2017; Paul et al. 2011). Since yield is related to white mold intensity (Fall et al. 2018; Lehner et al. 2016), which is known to be reduced by fungicide applications, we obtained estimates of the mean percent reduction of incidence and sclerotia mass by the selected fungicides.

The mean absolute difference in yield was used as the effect size; no transformation or standardization was required, given the statistical properties of the data. The yield difference was calculated directly after model fitting by subtracting estimated means for the treatments under comparison (fungicide minus nontreated plots) (Machado et al. 2017). For the two disease ratio variables (relative reduction of incidence and sclerotia mass), the log of the means ( $L_{I N C}$ and $L_{S C L}$ ) was used as the effect size in the model, given its better statistical properties than the ratio (Madden et al. 2016). The percent control was obtained by taking the difference of the estimated means of the logs $\left(\bar{L}_{I N C}\right.$ or $\left.\bar{L}_{S C L}\right)$, which equals the ratio of the two means (Paul et al. 2008). The mean ratio was used to obtain the control efficacy values $(\bar{C}$, percent reduction in the incidence or sclerotia mass) and their $95 \%$ confidence intervals (CIs) by back-transforming mean estimates of the ratio (difference in the logs) and the respective upper and lower limits of their 95\% CIs as follows: $\bar{C}=$ $\left(1-\left[\exp \left(\bar{L}_{I N C / S C L}\right)\right] \times 100\right)$ (Machado et al. 2017; Paul et al. 2008). The model can be written as equation 1 :

$$
Y_{i} \sim N\left(\mu, \Sigma+S_{i}\right)
$$

where $Y_{i}$ is the vector of $L$ ( $\log$ of the means of incidence or sclerotia mass) or mean yield for the six treatments plus the nontreated plots for the $i$ th study, $\mu$ is a vector representing the mean of $Y_{i}$ across all trials, $\Sigma$ is a $7 \times 7$ between-study variance-covariance matrix (for the seven treatments, including the nontreated plots), and $S_{i}$ is a within-study variance-covariance matrix for the $i$ th study. An unstructured $\Sigma$ matrix $(N)$ was used, given its better fit to the data compared to simplex structures such as compound symmetry and heterogeneous compound symmetry (data not presented). $N$ indicates a multivariate normal distribution. Maximum likelihood estimation models were fitted to the data using the rma.mv function of the $\mathrm{R}$ metafor package (Viechtbauer 2010).

Effect of moderators on yield response. The model was expanded to include moderator variables that could explain, at least in part, the heterogeneity of the effects across trials. First, we created a moderator variable for the incidence level in the check treatment (the baseline incidence). The crop yield response from using fungicides usually varies with baseline incidence: the greater the baseline disease, the greater the response, as reported for foliar diseases of maize and target leaf spot of soybean (Edwards Molina et al. 2019; Paul et al. 2011). For white mold, incidence was reported to be strongly associated with yield losses (Lehner et al. 2016). For simplified scenarios representing a low-disease and high-disease baseline, we separated the data into two sets of epidemics, $\geq 30 \%$ or $<30 \%$ incidence, which was the median value of the nontreated plots. Second, we tested whether white mold incidence and sclerotia mass treated as continuous variables (without grouping) significantly affected estimated yield for each fungicide treatment. The moderator variables were included and tested in the model as described elsewhere (Machado et al. 2017; Paul et al. 2008).

Effect of study design on network results. To test for network inconsistency attributable to the influence of study design, a factorialtype analysis of variance model was used to determine the significance of the treatment $\times$ design interaction, evaluated based on the Wald test statistic. The null hypothesis suggested that the network is consistent (Madden et al. 2016; Piepho 2014).

Probability of breaking even on fungicide cost. The probability of breaking even on the fungicide plus application cost $\left(F_{C}\right)$ was calculated using the meta-analytic estimates of mean yield

Table 1. Fungicide treatments applied for controlling white mold (Sclerotinia sclerotiorum) on soybean, evaluated in 74 cooperative fungicide trials conducted yearly from 2008/2009 to 2017/2018 in Brazil

\begin{tabular}{|c|c|c|c|c|c|}
\hline Fungicide active ingredient & Abbreviation & Commercial name & Sprays $(n)^{\mathbf{a}}$ & FRAC code ${ }^{b}$ & Dose $(\mathrm{g} / \mathrm{ha})$ \\
\hline Dimoxystrobin plus boscalid & $\mathrm{DIMO}+\mathrm{BOSC}$ & Spot & 2 & $11+7$ & 0.4 \\
\hline Fluazinam & FLUZ & Frowncide & 2 & 29 & 0.5 \\
\hline Fluopyram & FLUO & $\mathrm{PNR}^{\mathrm{c}}+$ Aureo $^{\mathrm{d}}$ & 2 & 7 & 0.2 \\
\hline Procymidone & PROC & Sumilex & 2 & 2 & 0.5 \\
\hline Carbendazim plus procymidone & $\mathrm{CARB}+\mathrm{PROC}$ & Carbomax + Sialex & 2 & $1+2$ & $0.5+0.5$ \\
\hline Thiophanate-methyl & TMET & Cercobin & 4 & 1 & 0.5 \\
\hline
\end{tabular}

\footnotetext{
${ }^{a}$ Number of applications: first spray at flowering and the following 10 days apart.

${ }^{\mathrm{b}}$ FRAC $=$ Fungicide Resistance Action Committee

${ }^{\mathrm{c}} \mathrm{PNR}=$ product not registered.

d Adjuvant.
} 
difference $(\bar{D})$, and the respective between-study variance $\widehat{\tau})$, between fungicide-treated and nontreated means for each class of disease scenario (high or low disease in the nontreated plots) (Table 2). Two representative treatments were selected: FLUZ, representing

Table 2. Statistics for estimates of the mean and respective lower and upper $95 \%$ confidence intervals $\left(C I_{\mathrm{L}}\right.$ and $\left.C I_{\mathrm{U}}\right)$ for yield response or difference $(\bar{D})$ between fungicide-treated and nontreated plots not conditioned (overall estimate) and conditioned (moderator analysis) to categorized white mold incidence on soybean representing a low-disease (incidence in the nontreated check $<30 \%$ ) or high-disease (incidence $>30 \%$ ) scenario, which significantly reduced heterogeneity of the estimates using data from 74 field trials conducted in Brazil from 2008/2009 to 2017/2018

\begin{tabular}{|c|c|c|c|c|c|c|c|}
\hline Fungicide $^{\mathrm{a}}$ & $k^{\mathbf{b}}$ & Condition & $\bar{D}$ & $C I_{\mathrm{L}}$ & $C I_{U}$ & $P$ value ${ }^{c}$ & Tau $(\widehat{\tau})^{\mathbf{d}}$ \\
\hline \multirow{3}{*}{$\begin{array}{r}\text { DIMO+ } \\
\text { BOSC }\end{array}$} & 72 & Overall & 626.7 & 521.7 & 731.7 & $<0.0001$ & $651,600.53$ \\
\hline & 38 & High disease & 821.1 & 694.3 & 947.9 & & \\
\hline & 34 & Low disease & 398.9 & 85.1 & 712.6 & & \\
\hline \multirow[t]{3}{*}{ FLUZ } & 73 & Overall & 623.4 & 523.5 & 723.3 & $<0.0001$ & $622,757.23$ \\
\hline & 38 & High disease & 801.8 & 677.9 & 925.8 & & \\
\hline & 35 & Low disease & 419.0 & 114.0 & 724.0 & & \\
\hline \multirow[t]{3}{*}{ FLUO } & 73 & Overall & 602.6 & 513.1 & 692.0 & $<0.0001$ & $630,246.18$ \\
\hline & 39 & sease & 765.9 & 657.1 & 874.7 & & \\
\hline & 34 & Low & 413.4 & 143.7 & 683.1 & & \\
\hline \multirow{3}{*}{$\begin{array}{r}\text { CARB+ } \\
\text { PROC }\end{array}$} & 27 & Overall & 579.7 & 463.2 & 696.3 & 0.0006 & $663,656.94$ \\
\hline & 10 & $\mathrm{Hig}$ & 763.2 & 604.1 & 922.4 & & \\
\hline & 17 & Lov & 375.8 & -3.6 & 755.3 & & \\
\hline \multirow[t]{3}{*}{ PROC } & 72 & Ove & 529.6 & 440.7 & 618.6 & $<0.0001$ & $596,457.08$ \\
\hline & 38 & Higl & 685.6 & 575.9 & 795.2 & & \\
\hline & 34 & Low disease & 346.2 & 73.1 & 619.3 & & \\
\hline \multirow[t]{3}{*}{ TMET } & 62 & Overall & 323.8 & 247.4 & 400.3 & 0.0015 & $495,396.05$ \\
\hline & 34 & High disease & 431.2 & 333.0 & 529.5 & & \\
\hline & 28 & Low & 198.8 & -43.2 & 440.8 & & \\
\hline \multicolumn{8}{|c|}{$\begin{array}{l}{ }^{\mathrm{a}} \mathrm{CARB}+\mathrm{PROC}=\text { carbendazim }(0.5 \mathrm{~g} / \mathrm{ha}) \text { plus procymidone }(0.5 \mathrm{~g} / \mathrm{ha}) \text {, } \\
\text { DIMO+BOSC }=\text { dimoxystrobin plus boscalid }(0.4 \mathrm{~g} / \mathrm{ha}), \text { FLUO = fluo- } \\
\text { pyram }(0.2 \mathrm{~g} / \mathrm{ha}), \mathrm{FLUZ}=\text { fluazinam }(0.5 \mathrm{~g} / \mathrm{ha}), \mathrm{PROC}=\text { procymidone } \\
(0.5 \mathrm{~g} / \mathrm{ha}), \text { and TMET }=\text { thiophanate-methyl }(0.5 \mathrm{~g} / \mathrm{ha}) . \\
{ }^{\mathrm{b}} \text { Number of trials in which each fungicide was evaluated. } \\
\left.{ }^{c} \text { Probability value (significance level }\right) \text { for the effect of fungicide on yield gain } \\
\text { (at the selected baseline disease). }\end{array}$} \\
\hline
\end{tabular}

a high-cost/more effective fungicide, and TMET, the low-cost/least effective option. The probability was calculated as

$$
P=\phi\left[\bar{D}-F_{C} / S_{P}\right) / \sqrt{\widehat{\tau}}
$$

where $\phi$ is the cumulative standard-normal function (Machado et al. 2017; Paul et al. 2011), $S_{P}$ is the soybean price, and $F_{\mathrm{C}}$ is the fungicide cost (product plus application). For each fungicide-baseline incidence, 48 scenarios were simulated $\left(6 S_{P} \times 8 F_{\mathrm{C}}\right)$, totaling 192 scenarios. Average prices of the fungicides were $\$ 40.00 \mathrm{USD} / \mathrm{ha}$ for FLUZ and \$7.5 USD/ha for TMET, considering an exchange rate of \$4.10 BRL equal to \$1 USD during September 2018 and fungicide prices of the 2017/2018 crop season. The operational costs were fixed at $\$ 10.00 \mathrm{USD} / \mathrm{ha}$ and the average soybean price used was \$378 USD/ton. The cost of TMET ranged from \$36 to $92 \mathrm{USD} / \mathrm{ha}$ (for four applications) and the cost of FLUZ ranged from $\$ 64$ to 120 USD/ha (for two applications). Tile plots of the probability classes of breaking even on fungicide costs were produced for each fungicide and disease level.

Data processing and availability. All data processing and analyses, as well as graphical work, were performed with $\mathrm{R}$ version 3.5.0 (R Core Team 2018). Texts and scripts were prepared as R Markdown documents rendered as a website where all data and the analyses are documented, reproducible, and openly available for download (osf.io/v7y2e). Supplementary File S1 contains a table with information for each trial used in the analysis, a map indicating where the trials were conducted, a graph for the network of treatments used for modeling yield response, and histograms describing properties of the disease and yield data.

\section{Results}

White mold and yield variables. Disease incidence and sclerotia mass in the nontreated plots ranged from 3.6 to $100 \%$ (median $31.8 \%$ ) and from 40.1 to $17,856.3 \mathrm{~g} / \mathrm{ha}$ (median $3,294.5 \mathrm{~g} / \mathrm{ha}$ ). There was a large variation in white mold incidence in the nontreated plots among the years and within a year, the latter reflecting field-specific differences in initial inoculum and weather conditions (data not available). Across seasons, the greatest median incidence (65\%) was recorded in the 2008/2009 season and the lowest median incidence (14.7\%) was recorded in the 2012/ 2013 season (Fig. 1A). Sclerotia mass was less variable than incidence among the years, with the highest amounts in the 2012/2013 season (median $6,730 \mathrm{~g} / \mathrm{ha}$ ) and the lowest amounts in the 2015/2016 season (median 1,147 g/ha) (Fig. 1B). As expected, the use of any of the fungicides
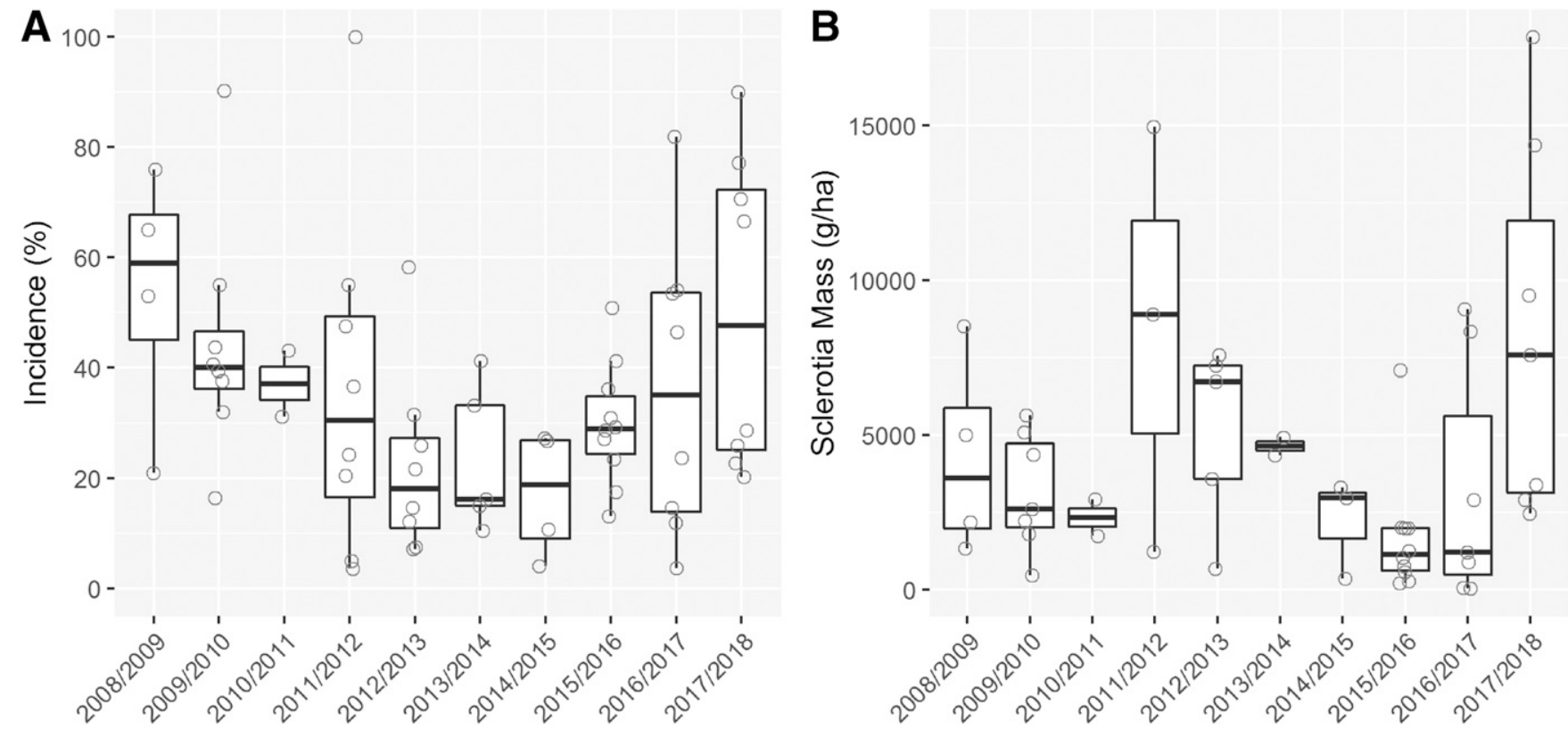

Fig. 1. Box plots for the within-season variation (across trials) of A, mean white mold incidence and $B$, mean sclerotia mass in the untreated check of 72 fungicide trials conducted in Brazil from 2008/2009 to 2016/2017. The thick horizontal line inside the box represents the median, the limits of the box represent the lower and upper quartiles, and the circles represent yearly means of each fungicide treatment (see Table 1). 
resulted in reduced white mold incidence and sclerotia production compared with the nontreated plots. Median values for incidence and sclerotia mass were mostly $<12 \%$ and $1,000 \mathrm{~g} / \mathrm{ha}$, respectively, when the fungicides were used (Fig. 2).

Baseline yield ranged from 1,438 to 4,813 kg/ha (median 2,989 kg/ha) across the trials. As expected, yield was greater in the fungicidetreated plots than in the nontreated plots $(P<0.0001)$ (Fig. 3B). Similar to the disease variables, there was a considerable variation in yield among the seasons and locations/trials within a season (each dot in Fig. 3A represents a location). The greatest median yield $(3,964 \mathrm{~kg} / \mathrm{ha})$ was observed in the 2014/2015 season and the lowest $(2,265.0$ $\mathrm{kg} / \mathrm{ha}$ ) was observed during the 2008/2009 crop season (Fig. 3).

Meta-analytic models. The percent control efficacy for incidence $\left(\bar{C}_{I N C}\right)$, obtained from back-transformation of the estimated differences of the log-transformed incidence in the fungicide-treated and nontreated plots, ranged from 54 to $83 \%$. Three fungicides (CARB+PROC, DIMO+BOSC, and FLUO) reduced incidence by at least $80 \%$ but did not differ significantly among them $(P>$ $0.30)$. These were followed by FLUZ, which had $>75 \%$ efficacy and differed significantly from PROC $(P=0.0001)$. The lowest control efficacy was obtained for TMET (54\%), which differed significantly from all other fungicides $(P<0.0001)$. The difference in percent control efficacy between the most and the least effective fungicide was 29.6 percentage points (Table 3 ). The Wald test for the treatment $\times$ design interaction showed that the network was consistent $(P=0.70)$.

For sclerotia mass reduction, the estimated mean control efficacy relative to the nontreated plots $\left(\bar{C}_{S C L}\right)$, obtained from

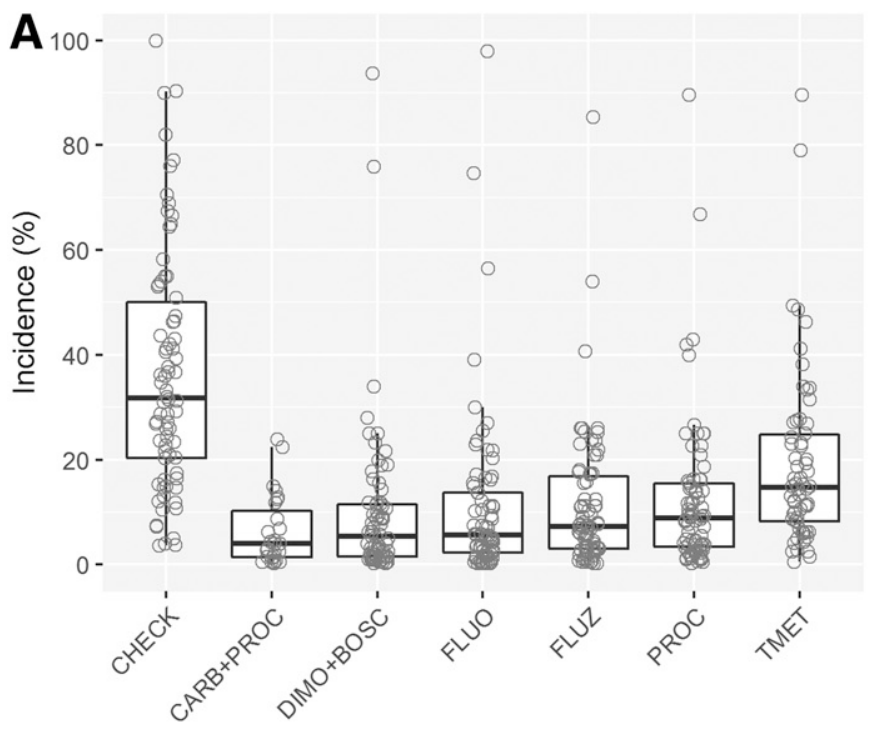

Fungicide

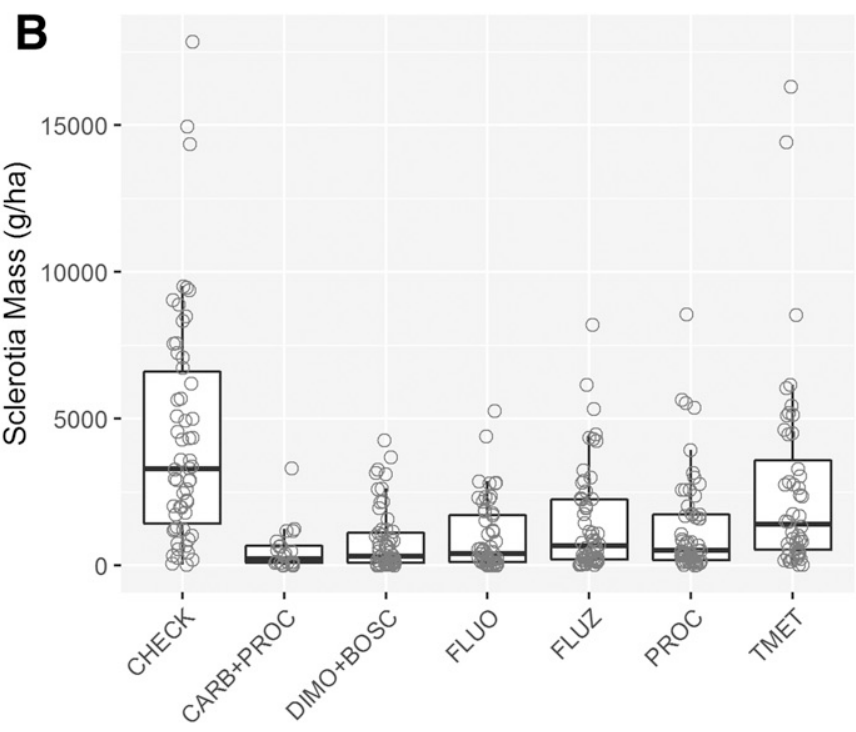

Fungicide

Fig. 2. Box plots and individual means of $\mathbf{A}$, white mold incidence (percentages) and $\mathbf{B}$, sclerotia mass production (grams/hectare). Treatments consisted of a nontreated check (CHECK) or treatment with two sprays of dimoxystrobin plus boscalid (DIMO+BOSC), fluazinam (FLUZ), fluopyram (FLUO), procymidone (PROC), carbendazim plus procymidone (CARB+PROC), and thiophanate-methyl (TMET) applied four times. The line inside the box represents the median and the circles represent each treatment mean.

A

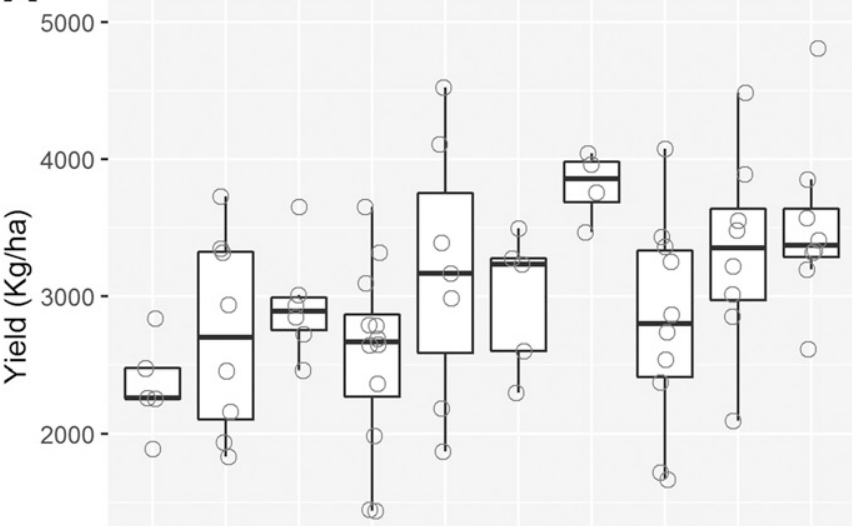

$1000-$

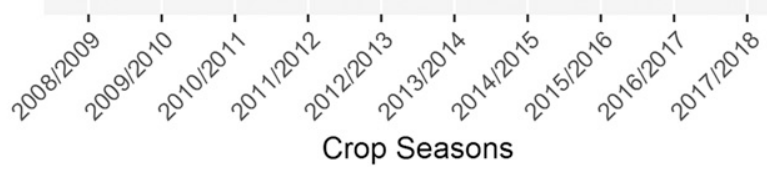

B

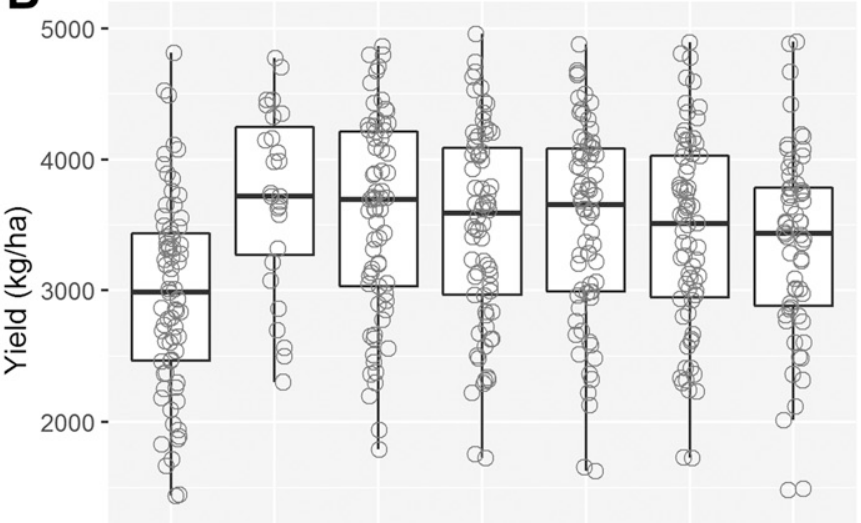

$1000-$

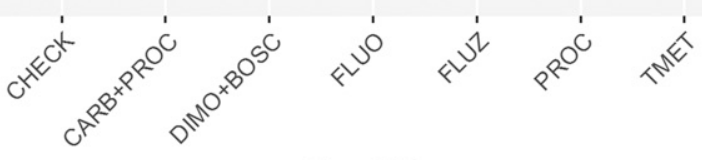

Fungicide

Fig. 3. Box plots for $\mathbf{A}$, means of grain yield (kilograms/hectare) in the nontreated check (CHECK) plots of trials conducted during 10 years and $\mathbf{B}$, means for a set of fungicide treatments evaluated in 74 trials. The following fungicides were applied twice at flowering and 10 days later: dimoxystrobin plus boscalid (DIMO+BOSC), fluazinam (FLUZ), fluopyram (FLUO), procymidone (PROC), and carbendazim plus procymidone (CARB+PROC). Thiophanate-methyl (TMET) was applied four times. 
back-transformation of the differences in the log-transformed original values, ranged from 51 to $87 \%$. Again, three fungicides, which were best for reducing incidence (CARB+PROC, DIMO+BOSC, and FLUO), showed the greatest percent reduction of levels $>80 \%$, followed by FLUZ and PROC with reduced efficacy, but $>75 \%$. The lowest reduction in sclerotia mass was estimated for TMET (51\%), which differed significantly from all other fungicides $(P<$ $0.0001)$. The greatest efficacy was estimated for CARB+PROC, which differed significantly from the three fungicides with efficacies estimated $<80 \%(P<0.05)$, but not from the other two $(P>0.3)$. The difference between the most and the least effective fungicide in reducing sclerotia mass was 36.2 percentage points (Table 3 ). The Wald test determined that network consistency was affected significantly by the study design $(P<0.0001)$.

There was a positive association between the estimated efficacies for the two disease variables, although differences between some of them are not too large. In general, the pattern was similar between the two variables, with CARB+PROC and TMET being the most and least effective for reducing both white mold incidence and sclerotia mass, respectively (Fig. 4).

The mean estimates of yield difference $(\bar{D})$ between fungicide treatments and the nontreated plots ranged from 323 to $626 \mathrm{~kg} / \mathrm{ha}$ among them. Yield gains as great as $600 \mathrm{~kg} / \mathrm{ha}$ were estimated for three fungicides: DIMO+BOSC, FLUZ, and FLUO $(P>0.3)$. These were followed by CARB+PROC (579 kg/ha), PROC (529 kg/ha), and TMET (323 kg/ha). The latter differed significantly from all other fungicides $(P<0.0001)$. The difference between the estimated means for the most and least effective fungicide was $303 \mathrm{~kg} / \mathrm{ha}$ (Table 2). The Wald test for the treatment $\times$ design interaction showed that the network was consistent $(P=0.99)$.

In general, the pattern of the relationship between control efficacy for each disease variable (incidence or sclerotia) and yield differences was consistent. The fungicide treatment leading to the greatest mean disease control, $\mathrm{CARB}+\mathrm{PROC}$, was less effective than three other fungicides with regard to yield gain and was similar to PROC alone, for which efficacy was 10 percentage points lower than

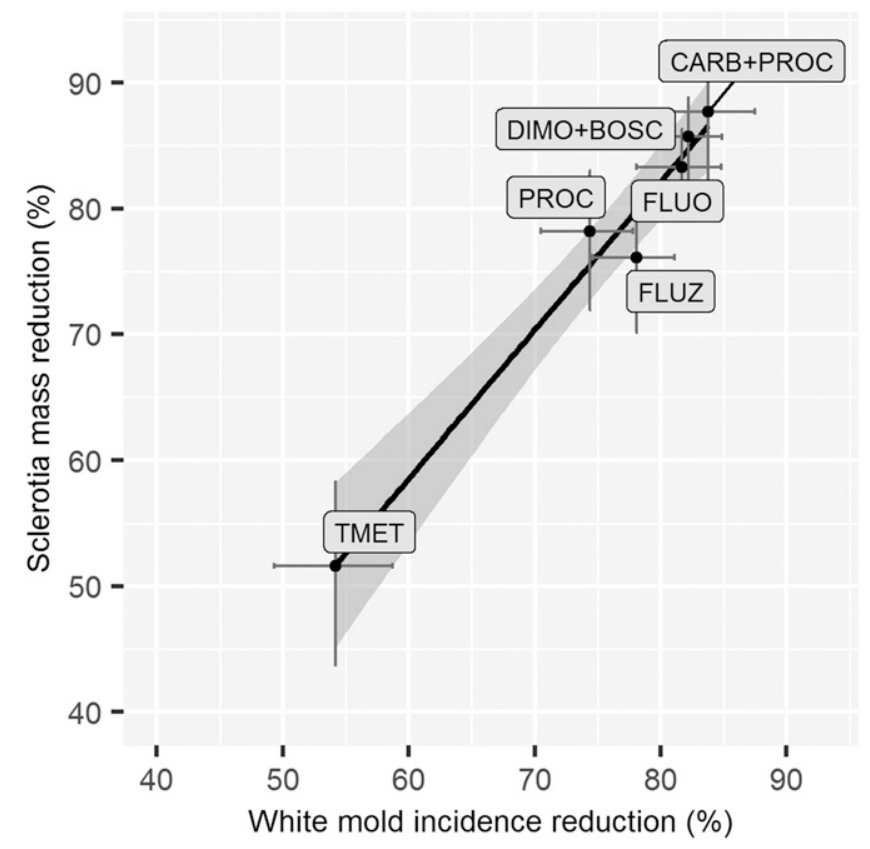

Fig. 4. Relationship between the percent reduction of white mold incidence and the percent reduction of sclerotia mass for five fungicides applied twice (flowering and 10 days later) and one applied four times (TMET) evaluated in a network metaanalysis of 74 trials from 2008/2009 to 2017/2018 in Brazil. Vertical and horizontal error bars represent the upper and lower limits of $95 \%$ confidence intervals around mean estimates for both response variables. $\mathrm{CARB}+\mathrm{PROC}=$ carbendazim plus procymidone, $\mathrm{DIMO}+\mathrm{BOSC}=$ dimoxystrobin plus boscalid, $\mathrm{PROC}=$ procymidone, FLUO = fluopyram, FLUZ = fluazinam, and TMET = thiophanate-methyl.
CARB+PROC. TMET consistently results in lower yield response and control compared to the other treatments (Fig. 5).

Effect of moderators on yield response. The expanded model including the categorical interaction term (baseline incidence) differed significantly from the simpler model based on the likelihood ratio test $(P=0.0018)$, meaning that incidence in the check explained a portion of the variability in yield difference. We determined that $\bar{D}$ was generally greater in the high-disease scenario (Table 2). Differences in $\bar{D}$ values between the low-disease and high-disease scenarios ranged from $232 \mathrm{~kg} / \mathrm{ha}$ (TMET) to as high as $422 \mathrm{~kg} / \mathrm{ha}$ (DIMO+BOSC) among the fungicide treatments. When these two disease variables were treated as continuous (white mold incidence and sclerotia production), they did not affect $\bar{D}(P>0.05)$.

Probability of breaking even on fungicide cost. The estimates of $\bar{D}$ and between-study variance $(\widehat{\tau})$ for each baseline disease (Table 2 ) were then used to calculate the probability of breaking even on fungicide costs. As expected, lower probability values were generally calculated for the low-disease scenario than the high-disease scenario and for the fungicides that were least effective in protecting yield (Fig. 6). For instance, four applications of TMET were more likely to be profitable ( $>50 \%$ probability) for the high-disease scenario only. The same was found for FLUZ, where probabilities ranged from 65 to $80 \%$ for breaking even on costs for the high-disease scenario. For the low-disease scenario, the higher chances of profitability (around 60\%) were calculated only for the more effective/ expensive fungicide (Fig. 6).

\section{Discussion}

In this study, network meta-analytic models allowed us to compare fungicides and provide quantitative estimates of effect sizes and their uncertainty using all available evidence in a unified modeling framework (Machado et al. 2017; Paul et al. 2008). Statistical analyses of the raw data, published in the annual reports, compared treatment means (using multiple-comparisons tests) at the trial level or combining all trials within a season, thus failing to properly provide an overall quantitative estimate (and its uncertainty) of yield benefits from using fungicides, a variable of greater importance for decisionmaking and economic analysis. Other known advantages of such analysis include increased statistical power, weighting of the estimates, and treating studies as random effects, thus allowing us to infer the causal effect to all possible trials that could be conducted (Madden et al. 2016).

Expansion of the meta-analytic model allowed us to explain at least a portion of the heterogeneity of the estimate of yield response through moderator analysis. Heterogeneity in yield responses was reduced when considering two classes of baseline disease, which represent two production situations influenced by environment,

Table 3. Overall means ${ }^{\mathrm{a}}$ and respective lower and upper $95 \%$ confidence intervals $\left(C I_{\mathrm{L}}\right.$ and $\left.C I_{\mathrm{U}}\right)$ of control efficacy (percent reduction) of white mold incidence $\left(\bar{C}_{I N C}\right)$ and sclerotia mass $\left(\bar{C}_{S C L}\right)$ for selected fungicide treatments evaluated over 10 years (2008/2009 to 2017/2018) across 74 field trials

\begin{tabular}{|c|c|c|c|c|c|c|c|c|}
\hline \multirow[b]{2}{*}{ Fungicide $^{b}$} & \multicolumn{4}{|c|}{ Incidence control (\%) } & \multicolumn{4}{|c|}{$\begin{array}{c}\text { Sclerotia mass } \\
\text { control }(\%)\end{array}$} \\
\hline & $k$ & $\bar{C}_{I N C}$ & $C I_{\mathrm{L}}$ & $C I_{\mathrm{U}}$ & $k$ & $\overline{\boldsymbol{C}}_{S C L}$ & $C I_{\mathrm{L}}$ & $C I_{\mathrm{U}}$ \\
\hline$\overline{\mathrm{CARB}+\mathrm{PROC}}$ & 27 & 83.8 & 79.1 & 87.5 & 22 & 87.7 & 81.9 & 91.6 \\
\hline DIMO+BOSC & 72 & 82.2 & 78.8 & 84.9 & 54 & 85.7 & 81.9 & 88.8 \\
\hline FLUO & 73 & 81.7 & 78.1 & 84.8 & 54 & 83.3 & 79.6 & 86.3 \\
\hline FLUZ & 74 & 78.1 & 74.6 & 81.1 & 56 & 76.1 & 70.1 & 80.9 \\
\hline PROC & 74 & 74.4 & 70.5 & 77.8 & 58 & 78.2 & 71.9 & 83.0 \\
\hline TMET & 62 & 54.2 & 49.3 & 58.7 & 48 & 51.6 & 43.7 & 58.3 \\
\hline
\end{tabular}

a An arm-based network meta-analysis was fitted to the log of the original treatment means weighted by the inverse of the sampling variance prior to obtaining the reported control efficacy.

${ }^{\mathrm{b}} \mathrm{CARB}+\mathrm{PROC}=$ carbendazim $(0.5 \mathrm{~g} / \mathrm{ha})$ plus procymidone $(0.5 \mathrm{~g} / \mathrm{ha})$, DIMO+BOSC $=$ dimoxystrobin plus boscalid $(0.4 \mathrm{~g} / \mathrm{ha})$, FLUO $=$ fluopyram $(0.2 \mathrm{~g} / \mathrm{ha})$, FLUZ = fluazinam $(0.5 \mathrm{~g} / \mathrm{ha})$, PROC $=$ procymidone $(0.5 \mathrm{~g} / \mathrm{ha})$, and TMET $=$ thiophanate-methyl $(0.5 \mathrm{~g} / \mathrm{ha})$ 
inoculum levels, and specific agronomic practices. This was expected, given the strong association between white mold and soybean yield (Lehner et al. 2016) and the more limited benefit of fungicides when baseline disease is relatively low or nearly absent (Edwards Molina et al. 2019; Paul et al. 2011). Indeed, a three-location study conducted in central Paraná, Brazil, could not detect evidence of yield benefits from using 17 treatments (combinations of fungicides and number of applications) evaluated for the control of white mold in soybean, compared with the nontreated plots (Wutzki et al. 2016). The incidence levels in those trials were $<32 \%$, which corroborates our conclusions of reduced yield benefit from using fungicides when conditions are not overly favorable for epidemics. Interestingly, in most cases, the fungicides evaluated in the study by Wutzki et al. (2016) effectively reduced disease incidence and sclerotia mass compared with the nontreated plots but failed to reduce disease severity. Appraisal of the means depicted in the bar graphs for each of the three trials of the study by Wutzki et al. (2016) suggests a numerical increase in yield, relative to the nontreated plots, for several fungicides at levels that fall within our estimated yield gain for the low-disease scenario. The failure to detect such differences, contrary to our study, may be attributable to the known low power of single experiments and the focus on the means rather than effect sizes, as in meta-analysis (Madden and Paul 2011).

Our analysis showed that three fungicides (DIMO+BOSC, FLUZ, and FLUO) performed best and similarly with regard to maximizing yield: mean estimates of yield response ranged from +765 to $+821 \mathrm{~kg} / \mathrm{ha}$ for the high-disease scenario. Intriguingly, CARB+ PROC was ranked first with regard to disease control (both incidence and sclerotia mass), but the estimated mean yield response was significantly lower than those three fungicides. In the previous meta-analysis of the FLUZ effect on soybean yield, data from 18 experiments conducted in the central (Campos Gerais) region of Paraná were used and an overall positive response of $413.9 \mathrm{~kg} / \mathrm{ha}$ (95\% CI, 344.6 to 483.1 ) was estimated using a random-effects model (Tupich et al. 2017). This mean estimate is lower than what we obtained in our study (523 to $723 \mathrm{~kg} / \mathrm{ha}$ ) for FLUZ applied twice. The authors also

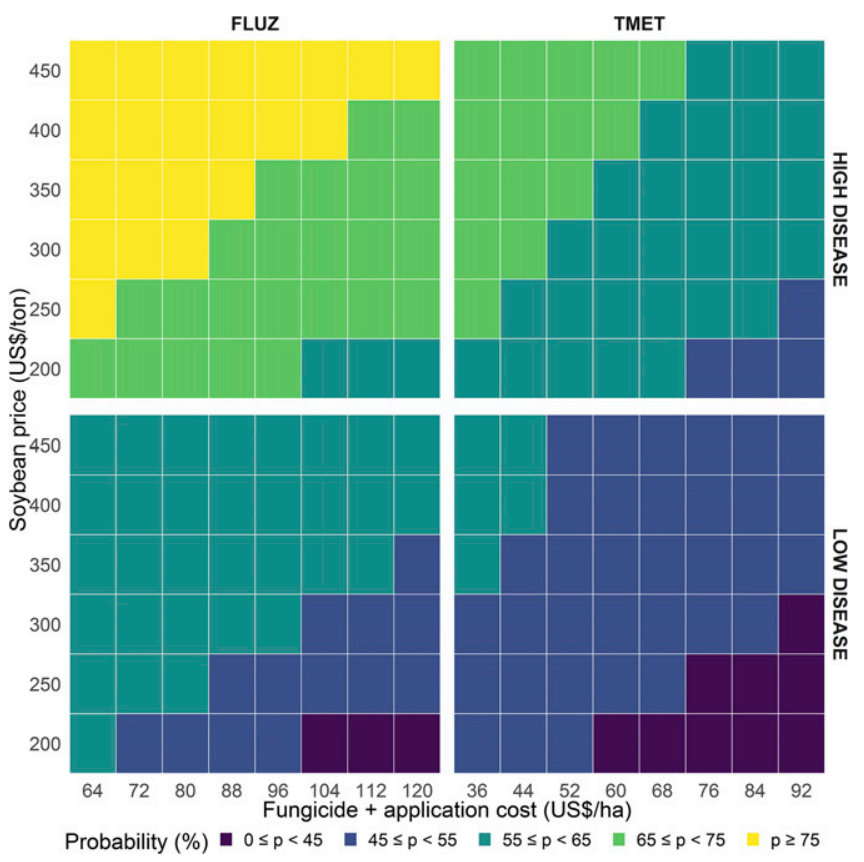

Fig. 6. Probability categories of breaking even on fungicide investment for different scenarios of soybean prices and fungicide costs (product price plus operational costs [fixed at $\$ 10.00$ USD]) for fluazinam (FLUZ) applied twice (flowering and 10 days later) and thiophanate-methyl (TMET) applied four times (flowering and 10day intervals) for white mold control. The probability for each fungicide treatment was calculated using estimates of the mean difference (D), and the respective between-study variance $(\widehat{\tau})$, conditioned to disease class representing a lowdisease (incidence $<30 \%$ ) or a high-disease (incidence $\geq 30 \%$ ) scenario (Table 2), obtained from meta-analysis of data from 74 trials conducted over 10 growing seasons in Brazil.
A

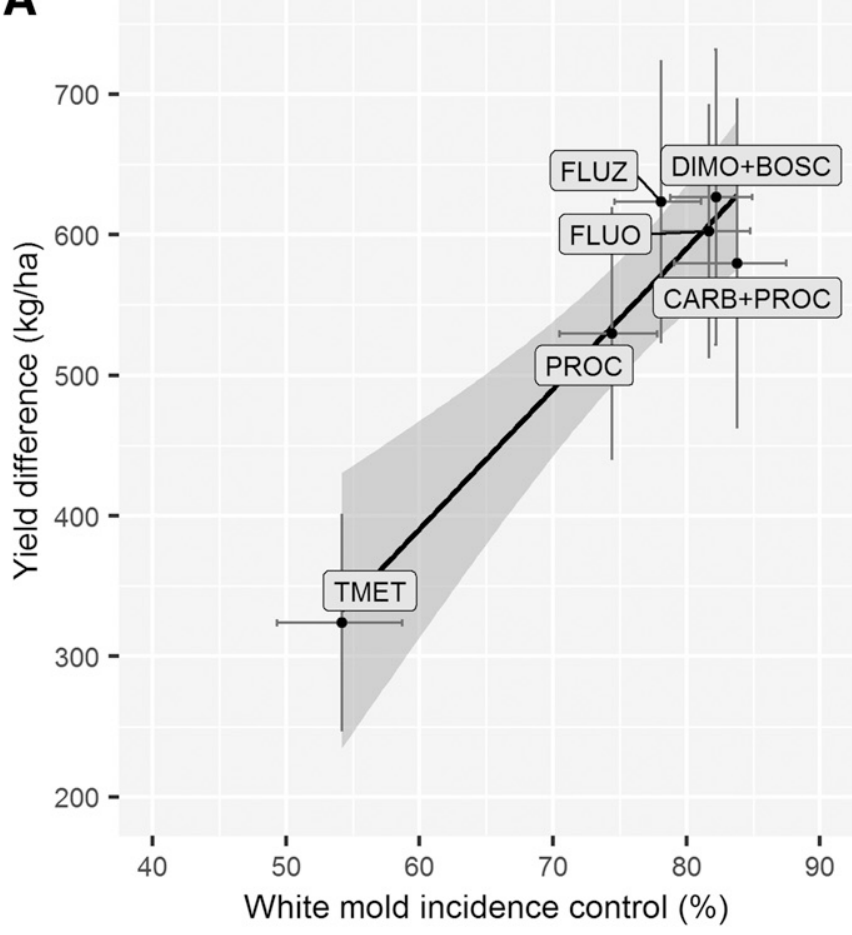

B

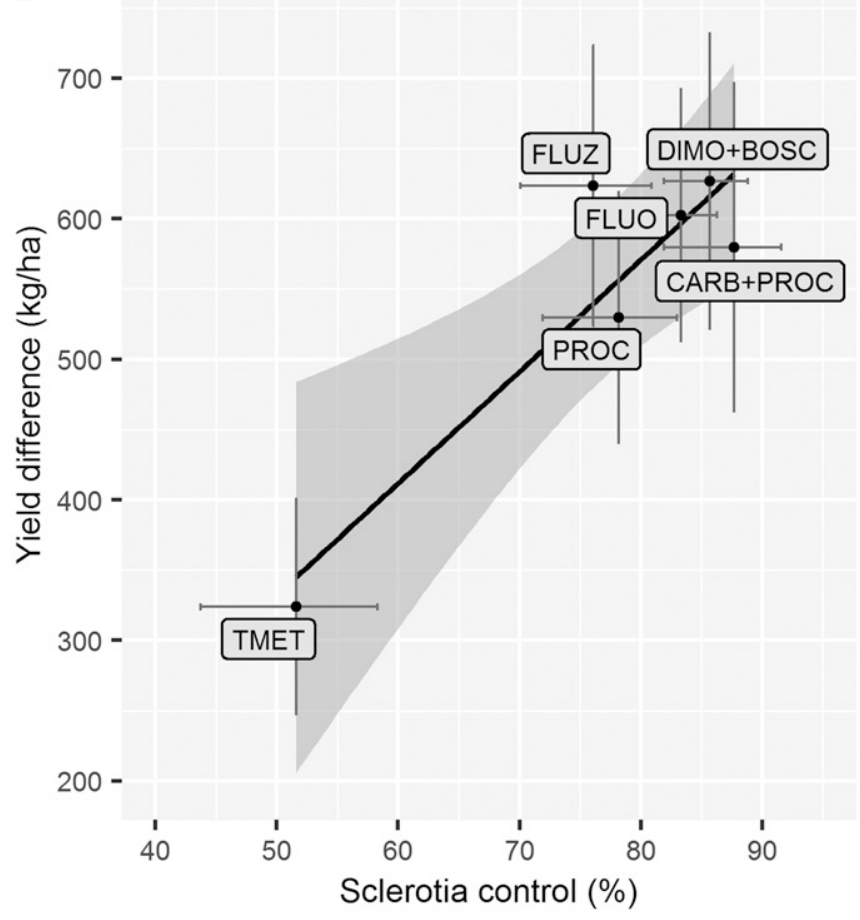

Fig. 5. Relationship between the percent reduction of $\mathbf{A}$, white mold incidence or $\mathbf{B}$, sclerotia amount and yield increase relative to nontreated plots, for five fungicides applied twice (flowering and 10 days later) and one applied four times (TMET). Data were obtained from a cooperative network of 74 independent fungicide trials in Brazil from $2008 / 2009$ to $2017 /$ 2018. Bars show the upper and lower limits of $95 \%$ confidence intervals around black point estimates for both responses. FLUO = fluopyram, FLUZ = fluazinam, PROC $=$ procymidone, $\mathrm{DIMO}+\mathrm{BOSC}=$ dimoxystrobin plus boscalid, CARB + PROC = carbendazim plus procymidone, and TMET, thiophanate-methyl. 
tested the effect of two disease categories as a moderator of the yield responses (15\% threshold for severity and 35\% threshold for incidence). However, contrary to our findings, the moderator did not affect yield gain. In that work, the number of entries (21 and 24) was much lower than in our study (73 entries) and evaluated treatments with one, two, or three applications of FLUZ. Such differences may explain incongruence in the findings, likely owing to the lower power of the study and trial-specific conditions. One noteworthy outcome, when the disease variables were treated as continuous in our expanded models, they did not significantly affect yield response. We believe that obtaining estimates of the two categories of disease, for which a significant difference was determined, is more important. Although more detailed information about the variation in the values of the predictors when the variable is continuous (e.g., all range of incidence) is lost, comparing the two groups (low-disease and high-disease) is more practical for decision-making, especially for situations when epidemic risk information is available, such as how likely an epidemic of concern will occur (De Wolf et al. 2003). Finally, the relationship between the disease incidence/sclerotia mass did not appear to be linear (data not shown), so the categorization was a more straightforward approach to learn about the relationship than fitting more complicated nonlinear models.

In a previous 2-year study in southern Brazil, FLUZ and PROC applied twice during flowering produced similar control efficacy when considering incidence or severity values. However, PROC led to a greater reduction of sclerotia mass than FLUZ, which is in agreement with our results (Berger-Neto et al. 2017). The authors suggested that this difference is likely attributable to the systemicity of PROC that extends the effect of the fungicide, preventing mycelium formation.

Our results showed that TMET, although applied four times, was the least effective for white mold control. In the midwestern United States, Mueller et al. (2002) reported 63\% efficacy of TMET applied twice during soybean flowering, which is above our estimated CI for this benzimidazole fungicide. This difference may be partially explained by location-specific factors and different doses $(0.84$ to $1.12 \mathrm{~kg} / \mathrm{a} . \mathrm{i} . / \mathrm{ha})$, which were greater than the doses applied in the Brazilian trials $(0.5 \mathrm{~kg} / \mathrm{a} . \mathrm{i} . / \mathrm{ha})$. Although it was least effective as determined by yield, our risk analysis showed that yield response from applying four sprays of TMET may likely result in break-even costs under more favorable conditions for epidemics, given its lower cost compared with the most effective (but more expensive) fungicides. However, greater probabilities were estimated for FLUZ, which is less prone to the development of fungicide resistance compared with TMET (Koenraadt et al. 1992; Lehner et al. 2015). Studies on fungicide resistance in Brazilian S. sclerotiorum populations are scarce, and Lehner et al. (2015) reported the presence of a TMET-resistant strain isolated from common bean plants $(P$. vulgaris $\mathrm{L}$.) in a production region where this fungicide is regularly used. Additional studies are needed to investigate whether TMET-resistant populations are present in soybean regions where application of this fungicide targeting white mold is frequent. Given the availability of more profitable fungicides and the risk of resistance, the use of TMET should not be encouraged in favor of the most effective yet profitable fungicides. Whether one or two sequential sprays of TMET or FLUZ are needed, our results determined that the probability of breaking even on direct costs (fungicide plus application) was lower and the estimated mean yield response was more uncertain (wider CI) under the low-disease rather than the high-disease risk scenario.

The information provided in our study may be of greater value should it be incorporated into a decision support system that takes into account not only economic scenarios (soybean price and application costs) but also disease risk, using white mold forecasting models such as the one developed in the United States for soybean (Willbur et al. 2018). We are not aware of warning systems being used for predicting white mold on Brazilian soybean. The current database of cooperative trials provides an important resource for validating existing models or developing new ones specific to Brazilian conditions.

\section{Acknowledgments}

The authors thank Dr. Eduardo S. G. Mizubuti and Dr. Sarah J. Pethybridge for useful comments on an earlier draft of the manuscript.

\section{Literature Cited}

Abawi, G. S., and Grogan, R. G. 1975. Epidemiology of diseases caused by Sclerotinia species. Phytopathology 69:899-904.

Adams, P., and Ayers, W. A. 1979. Ecology of Sclerotinia species. Phytopathology 69:896-898.

Allen, T. W., Bradley, C. A., Sisson, A. J., Byamukama, E., Chilvers, M. I., Coker, C. M., Collins, A. A., Damicone, J. P., Dorrance, A. E., Dufault, N. S., Esker, P. D., Faske, T. R., Giesler, L. J., Grybauskas, P., Hershman, D. E., Hollier, C. A., Isakeit, T., Jardine, D. J., Kemerait, R. C., Kleczewski, N. M., Koenning, S. R., Kurle, J. E., Malvick, D. K., Markell, S. G., Mehl, H. L., Mueller, D. S., Mueller, J. D., Mulrooney, R. P., Nelson, B. D., Newman, M. A., Osborne, L., Overstreet, C., Padgett, G. B., Phipps, P. M., Price, P. P., Sikora, E. J., Smith, D. L., Spurlock, T. N., Tande, C. A., Tenuta, A. U., Wise, K., Wrather, J. A., and Young-Kelly, H. 2017. Soybean yield loss estimates due to diseases in the United States and Ontario, Canada from 2010 to 2014. Plant Health Prog. 18:19-27.

Belova, A., Narayan, T., and Olkin, I. 2013. Methyl bromide alternatives for strawberry and tomato pre-plant uses: A meta-analysis. Crop Prot. 54:1-14.

Berger-Neto, A., Jaccoud-Filho, D. S., Wutzki, C. R., Tullio, H. E., and Pierre, M. L. C., Manfron, F., and Justino, A. 2017. Effect of spray droplet size, spray volume and fungicide on the control of white mold in soybeans. Crop Prot. 92:190-197.

Boland, G. J., and Hall, R. 1994. Index of plant hosts of Sclerotinia sclerotiorum. Can. J. Plant Pathol. 16:93-108.

Brent, K. J., and Hollomon, D. W. 2007. Fungicide Resistance in Crop Pathogens: How Can It Be Managed? FRAC Monograph No. 1, 2nd. rev. ed. Fungicide Resistance Action Committee, Brussels, Belgium.

Clarkson, J. P., Fawcett, L., Anthony, S. G., and Young, C. 2014. A model for Sclerotinia sclerotiorum infection and disease development in lettuce, based on the effects of temperature, relative humidity and ascospore density. PLoS One 9:e94049.

De Wolf, E. D., Madden, L. V., and Lipps, P. E. 2003. Risk assessment models for wheat Fusarium head blight epidemics based on within-season weather data. Phytopathology 93:428-435.

Edwards-Molina, J. P., Paul, P. A., Amorim, L., da Silva, L. H. C. P., Siqueri, F. V., Borges, E. P., Campos, H. D., Nunes, J., Jr., Meyer, M. C., and Martins, M. C. 2019. Meta-analysis of fungicides efficacy on soybean target spot and costbenefit assessment. Plant Pathol. 68:94-106.

Fall, M. L., Boyse, J. F., Wang, D., Willbur, J. F., Smith, D. L., and Chilvers, M. I. 2018. Case study of an epidemiological approach dissecting historical soybean Sclerotinia stem rot observations and identifying environmental predictors of epidemics and yield loss. Phytopathology 108:469-478.

Koenraadt, H., Somerville, S. C., and Jones, A. L. 1992. Characterization of mutations in the beta-tubulin gene of benomyl-resistant field strains of Venturia inaequalis and other plant pathogenic fungi. Phytopathology 82: 1348-1354.

Lehner, M. S., Del Ponte, E. M., Gugino, B. K., Kikkert, J. R., and Pethybridge, S. J. 2017. Sensitivity and efficacy of boscalid, fluazinam, and thiophanatemethyl for white mold control in snap bean in New York. Plant Dis. 101: 1253-1258.

Lehner, M. S., Paula, T. J., Jr., Silva, R. A., Vieira, R. F., Carneiro, J. E. S., Schnabel, G., and Mizubuti, E. S. G. 2015. Fungicide sensitivity of Sclerotinia sclerotiorum: A thorough assessment using discriminatory dose, $\mathrm{EC}_{50}$, high resolution melting analysis and description of new point mutation associated with thiophanate-methyl resistance. Plant Dis. 99: 1537-1543.

Lehner, M. S., Pethybridge, S. J., Meyer, M. C., and Del Ponte, E. M. 2016. Metaanalytic modelling of the incidence-yield and incidence-sclerotial production relationships in soybean white mould epidemics. Plant Pathol. 66:460-468.

Machado, F. J., Santana, F. M., Lau, D., and Del Ponte, E. M. 2017. Quantitative review of the effects of triazole and benzimidazole fungicides on Fusarium head blight and wheat yield in Brazil. Plant Dis. 101:1633-1641.

Madden, L. V., and Paul, P. A. 2011. Meta-analysis for evidence synthesis in plant pathology: An overview. Phytopathology 101:16-30.

Madden, L. V., Piepho, H. P., and Paul, P. A. 2016. Statistical models and methods for network meta-analysis. Phytopathology 106:792-806.

Meyer, M. C., Campos, H. D., Godoy, C. V., and Utiamada, C. M. 2014. Ensaios cooperativos de controle químico de mofo branco na cultura da soja: Safras 2009 a 2012. Documento 345. Embrapa Soja, Londrina, Brazil.

Meyer, M. C., Campos, H. D., Godoy, C. V., and Utiamada, C. M. 2016a. Ensaios cooperativos de controle biológico de mofo-branco na cultura da soja: Safras 2012 a 2015. Documento 368. Embrapa Soja, Londrina, Brazil.

Meyer, M. C., Campos, H. D., Godoy, C. V., Utiamada, C. M., Pimenta, C. B., Jaccoud Filho, D. S., Borges, E. P., Juliatti, F. C., Nunes, J., Jr., Carneiro, L. C., Silva, L. H. C. P., Sato, L. N., Goussain, M., Martins, M. C., Tormen, N. R., Balardin, S. A., and Venancio, W. S. 2017. Eficiência de fungicidas para controle de mofo-branco (Sclerotinia sclerotiorum) em soja, na safra 
2016/17: Resultados sumarizados dos ensaios cooperativos. Circular Técnica 133. Embrapa Soja, Londrina, Brazil.

Meyer, M. C., Campos, H. D., Godoy, C. V., Utiamada, C. M., Pimenta, C. B., Jaccoud Filho, D. S., Borges, E. P., Juliatti, F. C., Nunes, J., Jr., Carneiro, L. C., Silva, L. H. C. P., Sato, L. N., Madalosso, M., Goussain, M., Martins, M. C., Debortoli, M. P., Balardin, R. S., and Venancio, W. S. 2016b. Eficiência de fungicidas para controle de mofo-branco (Sclerotinia sclerotiorum) em soja, na safra 2015/2016: Resultados sumarizados dos ensaios cooperativos. Circular Técnica 122. Embrapa Soja, Londrina, Brazil.

Meyer, M. C., Campos, H. D., Godoy, C. V., Utiamada, C. M., Pimenta, C. B., Jaccoud Filho, D. S., Borges, E. P., Siqueri, F. V., Juliatti, F. C., Nunes, J., Jr., Carneiro, L. C., Silva, L. H. C. P., Sato, L. N., Madalosso, M., Martins, M. C., Balardin, R. S., Silva, S. A., and Venancio, W. S. 2015a. Eficiência de fungicidas para controle de mofo-branco (Sclerotinia sclerotiorum) em soja, na safra 2014/2015: Resultados sumarizados dos ensaios cooperativos. Circular Técnica 114. Embrapa Soja, Londrina, Brazil.

Meyer, M. C., Campos, H. D., Godoy, C. V., Utiamada, C. M., Pimenta, C. B., Machado, A. Q., Neto, D. C., Jaccoud Filho, D. S., Borges, E. P., Siqueri, F. V., Juliatti, F. C., Nunes, J., Carneiro, L. C., Silva, L. H. C. P., Madalosso, M., Balardin, R. S., Silva, S. A., and Venancio, W. S. 2015b. Eficiência de fungicidas para controle de mofo-branco (Sclerotinia sclerotiorum) em soja, na safra 2013/2014: Resultados sumarizados dos ensaios cooperativos. Circular Técnica 109. Embrapa Soja, Londrina, Brazil.

Meyer, M. C., Campos, H. D., Godoy, C. V., Utiamada, C. M., Seii, A. H., Dias, A. R., Jaccoud Filho, D. S., Borges, E. P., Juliatti, F. C., Nunes, J., Jr., Silva, L. H. C. P., Sato, L. N., Martins, M. C., and Venancio, W. S. 2018. Eficiência de fungicidas para controle de mofo-branco (Sclerotinia sclerotiorum) em soja, na safra 2017/18: Resultados sumarizados dos ensaios cooperativos. Circular Técnica 140. Embrapa Soja, Londrina, Brazil.

Mueller, D. S., Dorrance, A. E., Derksen, R. C., Ozkan, E., Kurle, J. E., Grau, C. R., Gaska, J. M., Hartman, G. L., Bradley, C. A., and Pedersen, W. L. 2002. Efficacy of fungicides on Sclerotinia sclerotiorum and their potential for control of Sclerotinia stem rot on soybean. Plant Dis. 86:26-31.

Ngugi, H. K., Lehman, B. L., and Madden, L. V. 2011. Multiple treatment metaanalysis of products evaluated for control of fire blight in the eastern United States. Phytopathology 101:512-522.

Ojiambo, P. S., Paul, P. A., and Holmes, G. J. 2010. A quantitative review of fungicide efficacy for managing downy mildew in cucurbits. Phytopathology 100:1066-1076.

Paul, P. A., Lipps, P. E., Hershman, D. E., McMullen, M. P., Draper, M. A., and Madden, L. V. 2008. Efficacy of triazole-based fungicides for Fusarium head blight and deoxynivalenol control in wheat: A multivariate meta-analysis Phytopathology 98:999-1011.

Paul, P. A., Madden, L. V., Bradley, C. A., Robertson, A. E., Munkvold, G. P., Shaner, G., Malvick, D. K., Allen, T. W., Grybauskas, A., Vincelli, P., and Esker, P. 2011. Meta-analysis of yield response of hybrid field corn to foliar fungicides in the U.S. Corn Belt. Phytopathology 101:1122-1132.

Peltier, A. J., Bradley, C. A., Chilvers, M. I., Malvick, D. K., Mueller, D. S., and Wise, K. A. 2012. Biology, yield loss and control of Sclerotinia stem rot of soybean. J. Integr. Pest Manag. 3:1-7.

Piepho, H. P. 2014. Network meta-analysis made easy: Detection of inconsistency using factorial analysis-of-variance models. BMC Med. Res. Methodol. 14:61.

Salanti, G., Higgins, J. P. T., Ades, A. E., and Ioannidis, J. P. A. 2008. Evaluation of networks of randomized trials. Stat. Methods Med. Res. 17:279-301.

Schwartz, H. F., and Steadman, J. R. 1978. Factors affecting sclerotium populations of, and apothecium production by, Sclerotinia sclerotiorum. Phytopathology 68:383-388.

Sumida, C. H., Canteri, M. G., Peitl, D. C., Tibolla, F., Orsini, I. P., and Araújo, F. A. 2015. Chemical and biological control of Sclerotinia stem rot in the soybean crop. Cienc. Rural 45:760-766.

Tupich, F. L. B., Fantin, L. H., da Silva, A. L., and Canteri, M. G. 2017. Impacto do controle do mofo-branco com fluazinam na produtividade da soja no Sul do Paraná: Metanálise. Summa Phytopathol. 43:145-150.

Viechtbauer, W. 2010. Conducting meta-analyses in R with the metafor package. J. Stat. Softw. 36:1-48.

Vieira, R. F., Paula, T. J., Jr. Teixeira, H., and de S. Carneiro, J. E. 2010. White mold management in common bean by increasing within-row distance between plants. Plant Dis. 94:361-367.

Willbur, J. F., Fall, M. L., Bloomingdale, C., Byrne, A. M., Chapman, S. A., Isard, S. A., Magarey, R. D., McCaghey, M., Mueller, B. D., Russo, J. M., Schlegel, J., Chilvers, M. I., Mueller, D. S., Kabbage, M., and Smith, D. L. 2018. Weather-based models for assessing the risk of Sclerotinia sclerotiorum apothecial presence in soybean (Glycine max) fields. Plant Dis. 102:73-84.

Willbur, J. F., McCaghey, M., Kabbage, M., and Smith, D. L. 2019. An overview of the Sclerotinia sclerotiorum pathosystem in soybean: Impact, fungal biology, and current management strategies. Trop. Plant Pathol. 44:3-11.

Wutzki, C. R., Jaccoud Filho, D. S., Berger Neto, A., Tullio, H. E., Juliatti, F. C., and Nascimento, A. J. 2016. Reduction of white mold level on soybean by fungicide management strategies. Biosci. J. 32:642-651.

Young, C. S., Clarkson, J. P., Smith, J. A., Watling, M., Phelps, K., and Whipps, J. M. 2004. Environmental conditions influencing Sclerotinia sclerotiorum infection and disease development in lettuce. Plant Pathol. 53:387-397. 